\title{
CYTOTOXIC AND GENOTOXIC ASSESSMENT OF SEWAGE TREATMENT PLANT EFFLUENT AT SHER-I-KASHMIR INSTITUTE OF MEDICAL SCIENCES(SKIMS) SOURA, SRINAGAR BY USING Allium CepaTest
}

\author{
Birjees Hassan ${ }^{1}$, Md. Niamat Ali ${ }^{*}$, Humaira Qadri ${ }^{3}$ \\ ${ }^{1}$ Department of Environmental Science, University of Kashmir, Srinagar190006, Jammu and Kashmir, India \\ ${ }^{2}$ Cytogenetics and Molecular Biology Research Laboratory, Centre of Research for Development, University of Kashmir, Srinagar-190006, J\&K, India \\ ${ }^{3}$ Department of Environmental Science, Sri Pratap College, Srinagar-190006, J\&K India
}

Received - December 13, 2019; Revision - January 11, 2020; Accepted - February 22, 2020

Available Online - February 25, 2020

DOI: http://dx.doi.org/10.18006/2020.8(1).48.53

KEYWORDS
Genotoxicity
Effluent
Chromosomal aberration
Anaphase bridges
Allium cepa

\begin{abstract}
Cyto-genotoxicity of hospital effluents collected from sewage treatment plant of SKIMS, was investigated using USEPA recommended Allium cepa test. Heterogeneous samples of both untreated and treated effluents were collected from the STP twice a day for three months and designated as complex mixture. Before measuring the root length of the onion bulbs, A. cepa plants were exposed to $25 \%, 50 \%$ and $100 \%$ concentrations for both untreated and treated effluent samples in the dark for $72 \mathrm{hrs}$. Significant results were observed in the root length evaluation and chromosomal aberration evaluation tests. Untreated effluent seems to be the most toxic on the root length of the A.cepa than treated samples. The lowest mean root length of onion bulbs was observed in untreated samples at $100 \%$ concentration which is found to be $0.61 \pm 0.28,0.95 \pm 0.21$ and $1.16 \pm 0.43 \mathrm{~cm}$ for first, second and third day respectively. Untreated sample from STP of SKIMS at $100 \%$ concentration gave the lowest mitotic index (MI) value of $4.56 \pm 1.44$ while as $50 \%$ and $25 \%$ concentration shows MI values of $16.32 \pm 2.09$ and $27.08 \pm 6.07$ respectively. Likewise, treated samples show mitotic index (MI) values of 18.2 \pm 4.65 , $3.96 \pm 5.54$ and $2.01 \pm 2.91$ at $25 \%, 50 \%$ and $100 \%$. The squash preparations from root tip cells of treated A. сера bulbs revealed different types of chromosomal aberrations such as metaphase stickiness, chromosomal breaks, c-mitosis, anaphase bridges and anaphase stickiness, indicating environmental toxicity risk. The treated effluent samples were found to be less genotoxic and cytotoxic, thus inferring that genotoxicity is reduced after the treatment process and A. cepa test has proved to be an effective tool in monitoring hospital effluents before beingdischarged into the environment.
\end{abstract}

* Corresponding author

E-mail: mdniamat@hotmail.com (Dr. Md Niamat Ali)

Peer review under responsibility of Journal of Experimental Biology and Agricultural Sciences.

Production and Hosting by Horizon Publisher India [HPI] (http://www.horizonpublisherindia.in/).

All rights reserved.
All the articles published by Journal of Experimental Biology and Agricultural Sciences are licensed under a Creative Commons Attribution-NonCommercial 4.0 International License Based on a work at www.jebas.org.

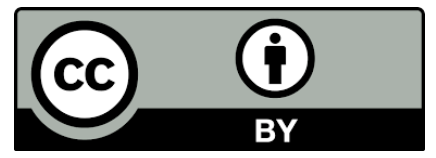




\section{Introduction}

Hospital effluents contain huge amounts of hazardous substances, such as un-metabolized pharmaceuticals, disinfectants, active substances, pigments, coloring agents, and radioactive elements, due to laboratory and research activities (Kummerer, 2001; Verlicchi et al., 2010; Stringer, 2011). It was reported that live organisms exposed to environmental agents have the ability to stimulate chromosomal changes which results in the growth of cancerous cells and finally lead to cell death. Hence, it is important to identify these toxic products and study their effects on animal, plant and particularly human population (Costa \& Menk, 2000; Silva et al., 2003; Paz et al., 2006).

The amount of wastewater generated by hospitals is estimated by water utilization. Waste waters produced by hospitals depends mostly on factors such as the type of hospital services provided, bed number, water accessibility, climatic conditions, level of health care facilities and local water-use practices (WHO, 2013). Based upon the given factors, the amount of wastewater produced by hospitals differs from hospital to hospital but it has been estimated at 400 to $1200 \mathrm{~L} \mathrm{bed}^{-1} \mathrm{day}^{-1}$ (Ibeh \& Omoruyi, 2011 ).Similarly, Tsakona et al., (2006) revealed an approximation on per capita production of wastewater in hospitals to be 1000 liters/person/day. In some countries like Japan, China, Greece, US, wastewater discharged from big hospitals is pretreated on-site (Pauwels \& Verstraete, 2006; Kosma et al., 2010; Liu et al., 2010), while as in many developing countries including India, most of the hospital wastewater is discharged in public sewers or in surface water courses or percolates into underlying groundwater aquifers with no or only partial treatment (Gupta et al., 2009).

Several chemical substances present in hospital effluents resis normal wastewater treatment. Residues of pharmaceuticals can be found in all wastewater treatment plant (WWTP) effluent, due to their inefficient removal in the conventional systems (Kümmerer, 2001; Kolpin et al., 2002; Petrovic et al., 2003; Snyder et al., 2003; Carballa et al., 2004).They end up in surface waters where they can influence the aquatic ecosystem and may accumulate through the food chain. Indeed, some of the substances found in wastewaters are genotoxic and are suspected to be a possible contributor to certain cancers observed in last decades (Jolibois \& Guerbet, 2006). For example, some drugs like cytostatic agents are genotoxic (Bassi \& Moretton, 2003).

Looking at greater significance of the problem, several researches have been carried out in the past few years to evaluate the genotoxicity of hospital effluents (Jolibois \& Guerbet, 2006; Ferk et al., 2009; Gupta et al., 2009; Alabi \& Shokunbi, 2011). While Magdaleno et al. (2014), investigating the toxicity and genotoxicity of wastewaters from the public hospital of Buenos Aires (Argentina), showed that $40 \%$ of the samples were genotoxic against A. cepa. Similarly, the genotoxicity assessment of wastewater from Hospital San Martín was evaluated by using $A$. cepa test. The results showed that the samples which were collected in summer 2003 and autumn 2004 were genotoxic and non-genotoxic to A. cepa respectively (Paz et al., 2006). In another study, the A. cepa test was used to evaluate the genotoxicity of a hospital effluent in Santa Maria, Rio Grande DoSul State, Brazil (Guerra \& Lopes, 2002). The chromosomal aberrations such as anaphasic bridges and micronucleus during telophase were observed, which indicated the environmental toxicity risk of hospital effluents.

Plants are essential components of the ecosystem and are, in general, more susceptible to ecological stress than other systems (Silva et al., 2003). A. cepa is one of the mostly used plant species in determining cytotoxicity and genotoxicity tests, particularly when monitoring environmental effluents. The mitotic index and replication index are used as indicators of cell proliferation (Gadano et al., 2002), which can be assessed using A. cepa test. In this study, A, cepa test was used to compare the genotoxicity and cytotoxicity of untreated and treated effluent discharge of SKIMS located in Srinagar, Jammu and Kashmir and thus analyzing the efficacy of the sewage treatment plant (STP) of the said hospital.

\section{Material and Methods}

The assays were carried out at the Cytogenetics and Molecular Plant laboratory-Center of research for development, university of Kashmir, India. The samples were collected both before and after treatment from the sewage treatment plant at SKIMS, Srinagar, Jammu and Kashmir, India. Untreated sample was taken from the main sewer of the hospital, where the entire wastewater from the hospital is collected before being treated. Treated wastewater was collected from the outlet of the treatment plant. Samples from SKIMS were collected twice daily for three months during its maximum activity period (usually 8:00am-6:00pm). The samples were carried to the laboratory and were filtered and acidified immediately. Until tested, the samples were stored at $4{ }^{\circ} \mathrm{C}$.

To estimate the root length or growth inhibition, the A. cepa bulbs were treated directly to control (tap water) and then in to $25 \%$, $50 \%$ and $100 \% \mathrm{v} / \mathrm{v}$ (hospital effluent/tap water) of each STP sample. Three A.cepa bulbs were utilized for each concentration of the hospital waste water samples and the control.

The samples were then tested for their mutagenic and cytotoxic potential in their crude state without being concentrated. The experiment was carried out according to Fiskejo (1993), with slight modifications. For the A. cepa test, three groups each with three bulbs were placed into hospital effluent at $25 \%, 50 \%$ and $100 \%$ concentration. The onion bulbs were allowed to grow for $72 \mathrm{hrs}$ in the distinct samples, where the control group remained in distilled 
water. When exposed roots have grown to a length of $1.5 \mathrm{~cm}$, about $0.5 \mathrm{~cm}$ of their tips was collected after $72 \mathrm{hrs}$ and immediately fixed in aceto: alcohol (1:3) for 20 minutes. The roots were transferred to $70 \%$ ethyl-alcohol and stored in refrigerator. A solution of $45 \%$ acetic acid ( 9 parts) and $1 \mathrm{M} \mathrm{HCl}(1$ part) was used for hydrolysis and maceration. The staining of the chromosomes was carried out with $2 \%$ carmine in $45 \%$ acetic acid (Pauwels \& Verstraete, 2006). After removing the root caps from well stained root tips, $1 \mathrm{~mm}$ of the meristematic or mitotic zones were immersed in a drop of $45 \%$ acetic acid on a clean slide and were submitted to squashing technique (Guerra \& Lopes, 2002). Examination of slides was done for determining mitotic index and chromosomal aberrations for each concentration and control. The slides were then observed under 1000x oil immersion light microscope and suitable pictures were captured as shown in Figure 1 (A-E). In case of each treatment five slides were prepared for each concentration and 500 cells were considered per slide. For statistical analysis, the ANOVA (one way) was carried out with SPSS computer programme significant at $\mathrm{p}<0.05$.The data value was expressed as mean with \pm standard deviation (SD) for mitotic index and chromosomal aberrations and root inhibition test was expressed as mean with \pm standard error.

\section{Results}

In this study, Allium cepa test was used to calculate the cytotoxicity and genotoxicity of the hospital effluent at SKIMS, Srinagar. The STP of SKIMS treats 25 lac litres of waste water per day which is operated and monitored by the sanitation and engineering department of the hospital. All undiluted waste samples showed cytotoxicity as well as genotoxicity, which was proved by cytogenetic parameters such as high inhibition of mitotic activity or low mitotic index (MI) values and high percentage of chromosomal and genomic aberrations. The mean root length of A. cepa grown at different concentrations of untreated and treated hospital samples are presented in Table 1. The mean root length of onion bulbs grown in $100 \%$ concentration of untreated effluent of SKIMS was $0.61 \pm 0.28,0.95 \pm 0.21$ and $1.16 \pm 0.43 \mathrm{~cm}$ for first, second and third day respectively. Similar growth pattern was observed at $25 \%$ and $50 \%$ concentration of untreated effluent samples of SKIMS sewage treatment plant. Similarly, the mean root length of onion bulbs grown in treated effluent at $100 \%$ concentration was $1.6 \pm 0.3,1.71 \pm 0.12$ and $1.90 \pm 0.05 \mathrm{~cm}$ for day 1,2 and $3^{\text {rd }}$ respectively. While those grown in $50 \%$ and $25 \%$ concentration of treated samples show increase in mean root length observed after 1,2 and $3^{\text {rd }}$ day. The study revealed that untreated effluents observed to be most toxic than treated effluents of STP of SKIMS. It shows that some sort of toxicity is reduced in hospital effluents after treatment into STP. At $95 \%$ confidence level ( $\mathrm{p}$ value $\leq 0.05$ ), it was observed that the root growth inhibition was statistically significant for untreated effluent samples at $25 \%, 50 \%$ and $100 \%$ while as treated effluents at $50 \%$ and $100 \%$ throughout the three days compared to the control.

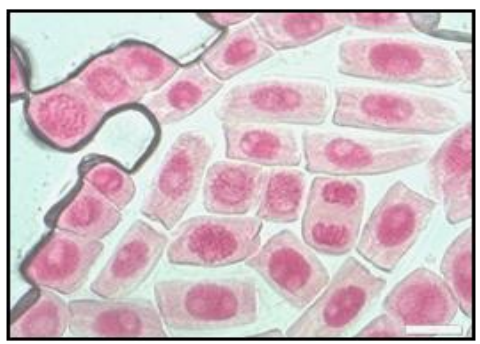

A. Anaphase Stickiness

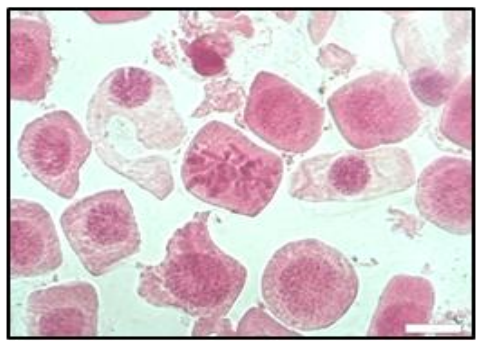

B. Chromosomal break
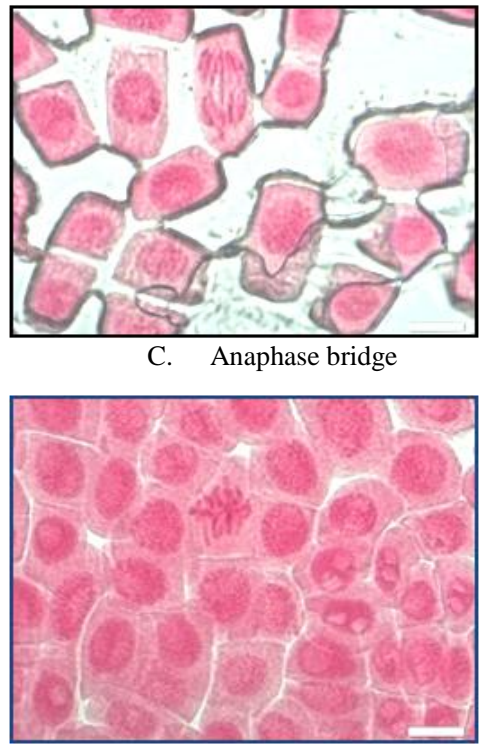

D. C-mitosis

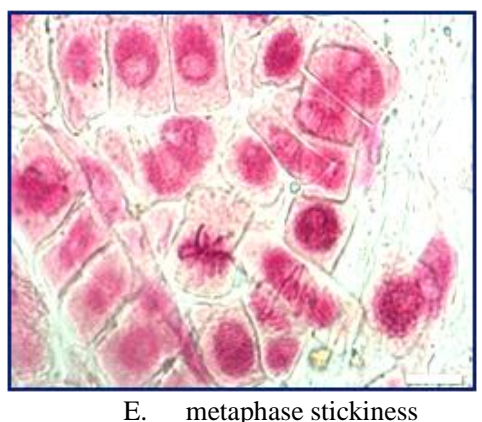

Figure 1 Chromosomal aberrations and their types observed in $A$. cepa meristematic cells exposed to different concentration of hospital effluent 
Table 1 MRL of A. cepa grown in different concentrations of the untreated and treated effluents of STP at SKIMS

\begin{tabular}{|lllll|}
\hline \multirow{2}{*}{ Sample site } & \multicolumn{1}{c}{ Conc. } & MRL+SD(cm)Day 1 & $\begin{array}{l}\text { MRL+SD(cm) } \\
\text { Day 2 }\end{array}$ & $\begin{array}{l}\text { MRL+SD(cm) } \\
\text { Day 3 }\end{array}$ \\
\hline Control & TW & $2.00 \pm 0.21$ & $3.1 \pm 0.15$ & $4.1 \pm 0.12$ \\
\hline \multirow{3}{*}{ SKIMS (untreated) } & $25 \%$ & $1.00 \pm 0.00^{*}$ & $1.43 \pm 0.35^{*}$ & $2.16 \pm 0.56^{*}$ \\
\cline { 2 - 5 } & $50 \%$ & $0.90 \pm 0.1^{*}$ & $1.36 \pm 0.30^{*}$ & $1.73 \pm 0.15^{*}$ \\
\hline \multirow{2}{*}{$\begin{array}{l}\text { SKIMS } \\
\text { (treated) }\end{array}$} & $100 \%$ & $0.61 \pm 0.28^{* *}$ & $0.95 \pm 0.2^{*} 1$ & $1.16 \pm 0.43^{*}$ \\
\hline
\end{tabular}

$* \mathrm{P} \leq 0.05$ level of significance of root growth inhibition as compared with the controls, Values are expressed in Means Root length \pm Standard deviation

Table 2: MI and CA induced in mitotic cells of A. cepa cells at different concentrations of untreated and treated hospital effluents of STP at SKIMS

\begin{tabular}{|ccccccccccc|}
\hline Sample site & Conc. & $\begin{array}{c}\text { Dividing } \\
\text { cells }\end{array}$ & MI & CB & MS & AB & CM & AS & $\begin{array}{c}\text { Total } \\
\text { abnormal-ity }\end{array}$ & $\begin{array}{c}\% \text { of total } \\
\text { abnormality }\end{array}$ \\
\hline Control & TW & 165.0 & $33.0 \pm 2.97$ & 0.0 & 0.2 & 0.2 & 0.0 & 0.2 & 0.6 & $0.12 \pm 0.54$ \\
\hline \multirow{2}{*}{$\begin{array}{c}\text { SKIMS } \\
\text { (untreated) }\end{array}$} & $25 \%$ & 135.4 & $27.08 \pm 6.07 *$ & 3.4 & 3.4 & 4.8 & 4.6 & 4.6 & 20.8 & $4.16 \pm 5.06$ \\
\cline { 2 - 10 } & $50 \%$ & 81.6 & $16.32 \pm 2.09$ & 5.4 & 6.2 & 6.8 & 6.8 & 6.0 & 31.6 & $6.32 \pm 6.42^{*}$ \\
\hline & $100 \%$ & 22.8 & $4.56 \pm 1.44^{* *}$ & 8.8 & 10.0 & 8.0 & 8.0 & 7.8 & 41.4 & $8.28 \pm 5.50^{*}$ \\
\hline $\begin{array}{c}\text { SKIMS } \\
\text { (Treated) }\end{array}$ & $50 \%$ & 127.2 & $25.44 \pm 2.33^{*}$ & 3.2 & 3.6 & 4.6 & 4.6 & 3.8 & 19.8 & $3.96 \pm 5.54 *$ \\
\cline { 2 - 10 } & $100 \%$ & 91.0 & $18.2 \pm 4.65$ & 7.8 & 8.2 & 5.0 & 5.6 & 5.4 & 32.0 & $6.4 \pm 4.30^{* *}$ \\
\hline
\end{tabular}

Data in the table is expressed as mean $\pm S D$; The Allium cepa bulbs were placed for $72 \mathrm{~h}$ in water (control) and hospital effluent samples The total number of cells analyzed for each treatment and control was 2500; Treatment time: Control = 72hrs, TW: Tap water,M1: Mitotic index, CA: Chromosomal Abnormalities, CB: Chromosomal break, MS: Metaphase stickiness, AB: Anaphase bridge, CM: C-mitosis, AS:

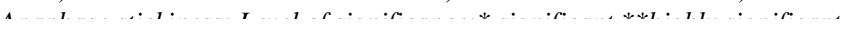

Table 2 showed the mitotic index (MI) of the onion bulbs of both plant. More frequent type of chromosomal aberrations was untreated and treated effluents at different concentrations collected metaphase stickiness followed by anaphase bridges and anaphase from STP of SKIMS treated. There was a reduction in the MI with stickiness in both untreated and treated samples of STP.

corresponding increase in the concentration of both untreated and treated hospital effluents when compared to the MI value of the control 33.0 \pm 2.97 . Untreated sample from STP of SKIMS at $100 \%$ concentration gave the lowest MI value of $4.56 \pm 1.44$ while as $50 \%$ and $25 \%$ concentration shows MI values of $16.32 \pm 2.09$ and $27.08 \pm 6.07$ respectively. Likewise, treated samples show MI values of $18.2 \pm 4.65,3.96 \pm 5.54$ and $2.01 \pm 2.91$ at $25 \%, 50 \%$ and $100 \%$ concentration respectively.

Table 2 also revealed most frequent type of chromosomal aberrations that were observed in the meristematic cells both in untreated and treated effluents from SKIMS sewage treatment plant. The observed aberrations were anaphase stickiness metaphase stickiness, chromosome breaks, c-mitosis and anaphase bridges. The aberrations in untreated samples of SKIMS was found to be greater in number than treated samples of sewage treatment

\section{Discussion}

In general, most of the onion bulbs exposed to different concentrations of the hospital effluent samples collected from sewage treatment plant of SKIMS, showed growth retardation when compared to the control (tap water). Specifically, the mean root lengths (MRL) of the onion bulbs cultivated in different concentrations of hospital effluents were in decreasing order as the concentration increases. The root tips of A. cepa treated in the hospital effluents were characterized by few distinct deformations such as swollen, twisted and crotchet roots when compared to control. The induction of root malformation in A. cepa has been proven to be positive indicator of toxicity (Silva et al., 2003; Bagatini et al., 2009). 
A considerable reduction in mitotic index and increase in chromosomal abnormalities were observed with increase in the concentration of hospital effluents both in untreated and treated samples. Whenever CA occurred, there are more or less distinct growth restrictions (Gadano et al., 2002). The reduction in the mitotic index with rising concentrations of the effluents is an indication of cytotoxicity (Rank \& Nielsen, 1993). Decrease of MI below $22 \%$ with respect to the control can cause deadly effects on the organisms. The decrease in mitotic index may be due to inhibition of DNA synthesis (Babatunde \& Bakare, 2006; Bakare et al., 2009) or blocking of cell at some stage of cell cycle (Olorunfemi \& Ehwre, 2010).

The chromosomal abnormalities such as stickiness, bridges, and laggards are some of the indications of genotoxicity (Olorunfemi et al., 2011). Table 2 shows most frequent type of chromosomal aberrations that were observed in the meristematic cells both in untreated and treated samples of sewage treatment plant of SKIMS. The observed aberrations were anaphase stickiness (Figure 1A), metaphase stickiness (Figure 1E), chromosomal breaks (Figure 1B), c-mitosis (Figure 1D) and anaphasic bridges (Figure 1C). The most commonly CA observed were bridges and sticky chromosomes. The large number of sticky chromosomes at anaphase and metaphase stages shows that the hospital waste water contains poisonous substances. Sticky chromosome is an indicator of poisoned chromosomes with sticky surface which possibly lead to death of cells (Antonise-Wiez, 1990). The stickiness may also arise due to disturbed metabolism of nucleic acid (Sudhakar et al., 2001). The anaphase bridges which were also seen as frequent type of aberration are formed mostly by breakage of chromosomes and such anomaly is also an indication of mutagenic events in the cell (Schneiderman et al., 1971). Another aberration, c-mitosis was observed which indicates the inhibition of spindle formation. It was reported that occurrence of c-mitosis is a sign of microtubule poison (Van't Hof, 1968) and chromosomal breaks may be due to clastogenicaction of the substance on DNA.

Comparing the results of untreated and treated effluents of sewage treatment plant of SKIMS, it was analyzed that the total abnormality and inhibition of cell division was high at higher concentration both in untreated and treated effluents. This clearly demonstrates the presence of certain cytotoxic and genotoxic compounds in the hospital effluent. It was also confirmed that untreated samples shows more genotoxicity than treated samples which clearly indicate that the toxic and mutagenic substances were present in bulk quantity in untreated samples. Although the toxicity is reduced to a great extend but the results shows some sort of chromosomal aberrations in treated samples.

The study demonstrates that the remaining cytotoxicity and genotoxicity reinforces the concept that the sewage treatment plant (STP) has crossed its utmost limit. The results warned about the necessity to develop efficient treatment methods to mitigate the environmental impacts of hospital effluents before the humans and other organisms can be exposed to these toxic substances.

\section{Conflict of Interest}

Authors would hereby like to declare that there is no conflict of interests that could possibly arise.

\section{References}

Alabi OA, Shokunbi OS (2011) Toxicological effects of hospital wastewater using animal bioassays. Annals of Biological Research 2:265-275.

Antonise-Wiez D (1990) Analysis of the cell cycle in root meristem of Allium cepa under the influence of Ledakrin. Folia Histochemical Cytobiologia 26:79-96.

Babatunde BB, Bakare AA (2006) Genotoxicity screening of waste from Agbara Industrial Estate, Nigeria evaluated with the Allium test. Pollution Research 25:227-234.

Bagatini M, Vasconcelos T, Laughinghouse IVHD, Martins A, Tedesco S (2009) Biomonitoring hospital effluentsby the Allium cepa L. test. Bulletin of Environmental Contamination and Toxicology 82:590-592.

Bakare AA, Okunola AA, Adetunji OA, Jenmi HB (2009) Genotoxicity assessment of Pharmaceutical effluent using four bioassays. Genetic and Molecular Biology 32:373-381.

Bassi MD, Moretton J (2003) Mutagenicity of antineoplastic drug residues treated in health care waste autoclave. Bulletin of Environmental Contamination and Toxicology $71: 170-175$.

Carballa M, Omil F, Lema M, Llompart C, Garcia-Jares I, Rodriguez M, Gomez, Ternes T (2004) Behavior of pharmaceuticals, cosmetics and hormones in a sewage treatment plant. Water Research 38:2918-2926

Costa RMA, Menk CFM (2000)Biomonitoramento de mutage neseambiental. In: Biotecnologia (Ed) Cie nncia \& Desenvolvimento 2:24-26.

Ferk F, Mijsík M, Grummt T, Majer B, Fuerhacker M, Buchmann C, Vital M, Uhl M, Lenz K, Grillitsch B, Parzefall W, Nersesyan A, Knasmüller S (2009) Genotoxic effects of wastewater from an oncological ward. Mutation Research 672: 69-75.

Fiskejo G (1993) The Allium test. In: Wastewater monitoring Environmental Toxicology and Water Quality 8:291-298.

Gadano A, Gurni A, López P, Ferraro G, Carballo M (2002) In vitro genotoxic evaluation of the medicinal plant Chenopodiumambrosioides L. Journal of Ethnopharmacology 81:11-16. 
Guerra M, Lopes MJS (2002) Como observarcromossomos-Um guia de te 'cnicasemcitogene 'tica vegetal, animal e humana. FUNPEC, vol 1. Ribeira ̃o Preto 2002;131.

Gupta P, Mathur N, Bhatnagar P, Nagar P, Srivastava S (2009) Genotoxicity evaluation of hospital wastewaters. Eco-toxicology and Environmental Safety 72:1925-1932.

Ibeh IN, Omoruyi MI (2011) Seasonal Dynamics in the Physiochemical Parameters of Hospital Effluent from a University Teaching Hospital based in Southern Nigeria. Journal of Asian Scientific Research.1:7-17I.

Jolibois B, Guerbet M (2006) Hospital wastewater genotoxicity. Annals of Occupational Hygiene 50: 89-196.

Kolpin D, Furlong E, Meyer M, Thurman M, Zaugg S, Barber L, Buxton H (2006)Pharmaceuticals, hormones, and other organic wastewater contaminants in U.S. streams, 1999-2000: a national reconnaissance. Environmental Science and Technology 36:1202-1211.

Kosma CI, Lambropoulou DA, Albanisa TA (2010) Occurrence and removal of PPCPs in municipal and hospital wastewaters in Greece. Journal of Hazardous Materials 179:804-817.

Kummerer K (2001) Drugs in the environment: emission of drugs, diagnostic aids and disinfectants into wastewater by hospitals in relation to other sources-a review. Chemosphere 45:957-969.

Liu Q, Zhou Y, Chen L, Zheng X (2010)Application of MBR for hospital wastewater treatment in China. Desalination 250:605-608.

Magdaleno A, Juárez ÁB, Dragani, Saenz ME, Paz M, Moretton J (2014) Ecotoxicological and genotoxic evaluation of Buenos Aires city (Argentina) hospital wastewater. Journal of Toxicology 1-10.

Olorunfemi DI, Ehwre EO (2010) Chromosomal aberrations induced in root tips of Allium cepa by squeezed garri extracts. Report and Opinion 2:166-171.

Olorunfemi DI, Okoloko GE, Bakare AA, Akinboro A (2011) Cytotoxic and genotoxic effects of cassava effluents using Allium cepa test. Research Journal of Mutagenesis 1:1-9.

Pauwels B, Verstraete W (2006) The treatment of hospital wastewater: An appraisal. Journal of Water Health 4:405-416.

Paz M, Muzio H, Mendelson A, Magdaleno A, Tornello C, Balbis
N, Moretton J (2006) Evaluation of genotoxicity and toxicity of Buenos Aires city hospital wastewater samples. Journal of the Brazilian Society of Ecotoxicology 1:1-6.

Petrovic M, Gonzalez S, Barcel'o D (2003) Analysis and removal of emerging contaminants in wastewater and drinking water. Trend in Analytical Chemistry 22:685-696.

Rank J, Nielsen MH (1993) A modified Allium test as a tool in the screening of genotoxicity of complex mixtures. Hereditas 118:49-53.

Schneiderman MH, Dewey WC, Highfield DP (1971) Inhibition of DNA synthesis in synchronized Chinese hamster cell treated in G1 with cycloheximide. Experimental Cell Research 67:147-155.

Silva J, Erdtmann B, Henriques JAP (2003) Gene 'ticatoxicolo 'gica. Alcance, Porto Alegre Pp. 70-75.

Snyder SA, Westerhoff P, Yoon Y, Sedlak DL (2003)Pharmaceuticals, personal care products, and endocrine disruptors in water: implications for the water industry. Environmental Engineering and Science 20: 449-469.

Stringer R (2011) Medical Waste and Human Rights. Submission to the UN Human Rights Council Special Rapporteur. Health Care Without Harm.

Sudhakar R, Gowda N, Venu G (2001) Mitotic abnormalities induced by silk dyeing industry effluents in the cells of Allium cepa. Cytologia 66:235-239.

Tsakona M, Anagnostopoulou E, Gidarakos E (2006) Hospital waste management and toxicity evaluation: A case study. Waste Management 27:912-920.

Van't Hof J (1968) The action of IAA and kinetin on the mitotic cycle of proliferative and stationary phase excised root meristem. Experimental Cell Research 51:167-176.

Verlicchi P, Galletti A, Petrovic M, Barcel'o D (2010)Hospital effluents as a source of emerging pollutants: an overview of micropollutants and sustainable treatment options. Journal of Hydrology 389:416-428.

WHO (2013) Safe management of wastes from health-care activities Second edition. In: Chartier Y, Emmanuel J, Pieper U, Pruss A, Rushbrook P, Stringer R, Townend W, Wilburn S, Zghondi R ((Eds), WHO Library Cataloguing-in-Publication Data.. 